\title{
First report of zucchini yellow mosaic virus in muskmelon (Cucumis melo) in Korea
}

\author{
In-Sook Cho ${ }^{1}$ • Bong-Nam Chung ${ }^{1}$ • Sun-Jung Kwon ${ }^{1}$ • Ju-Yeon Yoon ${ }^{1} \cdot$ Gug-Seoun Choi ${ }^{1} \cdot$ Boram Kim $^{2}$. \\ John Hammond ${ }^{3} \cdot$ Hyoun-Sub Lim ${ }^{2}$ (I)
}

Received: 1 November 2018 / Accepted: 29 December 2018 / Published online: 16 January 2019

(C) Società Italiana di Patologia Vegetale (S.I.Pa.V.) 2019

Keywords ZYMV $\cdot$ Cucumis melo $\cdot$ Korea

Green vein banding and severe mottle on leaves of Cucumis melo L. (muskmelon cv. 'Santafe') were observed in plants grown in almost $90 \%$ of plastic houses examined in Wanju, Korea in 2017. Disease incidence of more than $90 \%$, and losses of $90 \%$ were estimated across 15 plastic houses $\left(6600 \mathrm{~m}^{2}\right)$. Flexuous filamentous particles (approximately $710 \times 13 \mathrm{~nm}$ ) typical of potyviruses were observed by electron microscopy of leaves with virus-like symptoms. The presence of two potyviruses infecting Cucurbitaceae, zucchini yellow mosaic virus (ZYMV) and watermelon mosaic virus, as well as other viruses infecting Cucurbitaceae, such as cucumber mosaic virus, cucurbit aphid-borne yellow virus, tobacco ringspot virus and squash mosaic virus was tested by RTPCR using specific primers. Results showed that ZYMV, but no other cucurbit virus, was detected. To confirm specific amplification of ZYMV, the coat protein (CP) gene product that was obtained by RT-PCR using primers ZYMV-895-For: CAAGGAGACACCGTAATGCTCCAA and ZYMV-895Rev: TGCATTGTTCACACCTAACAGG, designed based on a multiple sequence alignment, was sequenced and submitted to GenBank as accession No. MF804411. The ZYMV isolate identified is this study was named ZYMV-me-SR.

Hyoun-Sub Lim

hyounlim@cnu.ac.kr

1 Horticultural \& Herbal Crop Environment Division, National Institute of Horticultural \& Herbal Science, RDA, Jeollabuk-do 100, South Korea

2 Department of Applied Biology, Chungnam National University, Daejeon 305-764, South Korea

3 United States Department of Agriculture-Agricultural Research Service, United States National Arboretum, Floral and Nursery Plants Research Unit, Beltsville, MD 20705, USA
Characterizing the phylogenetic relationship of ZYMV-meSR and other ZYMV isolates within the CP gene by the neighbor-joining method with 1000 bootstrap replications using MEGA 7 (Kumar et al. 2016) showed that ZYMVme-SR clustered with other isolates in group A previously described by Wang and Li (2017). Although ZYMV was first reported to infect melon crops in 1979 (Lecoq et al. 1981), this is the first report of ZYMV in Cucumis melo L. (muskmelon) in Korea.

Publisher's note Springer Nature remains neutral with regard to jurisdictional claims in published maps and institutional affiliations.

\section{References}

Kumar S, Stecher G, Tamura K (2016) MEGA7: molecular evolutionary genetics analysis version 7.0 for bigger datasets. Mol Biol Evol 33(7):1870-1874

Lecoq H, Pitrat M, Clément M (1981) Identification et caractérisation d'un potyvirus provoquant la maladie du rabougrissement Jaune du Melon. Agronomie 1:827-834

Wang D, Li G (2017) Biological and molecular characterization of zucchini yellow mosaic virus isolates infecting melon in Xinjiang, China. Can J Plant Pathol 39:48-59 